\title{
バイモルフ型静電マイクロアクチュエータのカ特性
}

\section{Dynamic Characteristics of a Bimorph Electrostatic Microactuator}

\author{
深町 尚貴 (九州工業大学) ○國本 悠司（九州工業大学） \\ 河本 祐樹 (九州工業大学) 正 安田 隆 (九州工業大学)
}

Naoki FUKAMACHI, Kyushu Institute of Technology, 2-4 Hibikino, Wakamatsu-ku, Kitakyushu

Yuji KUNIMOTO, Kyushu Institute of Technology

Yuuki KAWAMOTO, Kyushu Institute of Technology

Takashi YASUDA, Kyushu Institute of Technology

\begin{abstract}
Four types of bimorph electrostatic microactuators having different structure and size were fabricated and tested. They consist of bimorph structure beams made of poly-Si and $\mathrm{Au} / \mathrm{Cr}$, and their performance is achieved by using several beams connected in series and bending them sequentially with electrostatic force. Forces generated by the microactuators were measured with a Si cantilever and a laser displacement meter. The relationship between applied voltage and generated force showed that the actuator which had longer beams located closer to a substrate generated larger force by applying lower voltage.
\end{abstract}

Keywords: Electrostatic microactuator, Low voltage, Large deflection, Bimorph structure, Force measurement

\section{1. はじめに}

筆者らは, Au/poly-Si バイモルフ構造を有する複数の beam をスパイラル状に接続することで, $10 \mathrm{~V}$ 程度の低電圧 で大変形可能な静電マイクロアクチュエータを作製した ${ }^{[1]}$. さらに, 出力部分が中心にあるため外部への出力が困難で あった構造を改良し, beam の組み合わせを変更することで 外部出力を容易にしたマイクロアクチュエータを考案した [2]. 本講演では, このマイクロアクチュエータの発生力を 力測定用の片持ち梁とレーザ変位計により測定した結果を 報告するとともに，この結果を考察することにより低電压 で大きな発生力を得るのに必要なアクチュエータの構造な どについて議論する。

(a) Type 1

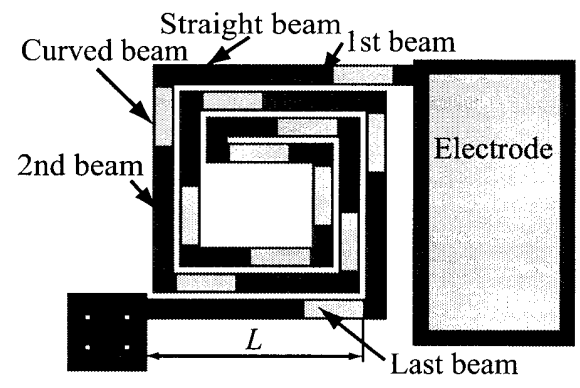

(b) Type 2

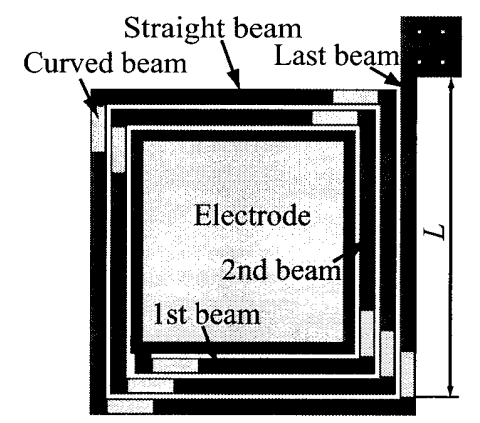

Fig. 1 Structure of two types of electrostatic microactuators.

\section{2. 橝造と動作原理}

Fig.1 に, 外部出力を容易にしたアクチュエータの構造と 寸法を示す. Fig.1(a)の Type 1 は, 長さが徐々に短くなる beam を組み合わせ, 中心部分で折り返し, 長さが徐々に長
くなる beam を組み合わせた構造を有する。また，Fig.1(b) の Type 2 は, 電極部分を中心にし, 長さが徐々に長くなる beam をスパイラル状に組み合わせた構造を有する。それぞ れのアクチュエータにおける全ての beam は同じ構造をし ており, poly-Si 薄膜から成る真直梁部(Straight beam) と poly-Si 薄膜上に Cr 薄膜と $\mathrm{Au}$ 薄膜が成膜されたバイモルフ 構造から成る曲り梁部(Curved beam)で構成される。曲り梁 部は, 初期状態において poly-Si 薄膜と $\mathrm{Au}$ 薄膜の残留応力 の違いにより上方に反り上がっている。

これら 2 種類のアクチュエータは, 以下のような原理で 動作する．基板に固定された電極(Electrode)から伸びた $1 \mathrm{st}$ beam と基板間には初期状態において非常に小さな隙間が 構成されているため, 低い電圧を印加しても大きな静電力 が発生し，それにより 1st beam は基板に接触するまで変形 する．1st beam が基板に接触することで，2nd beam と基板 間に非常に小さな隙間が構成されるので，ほぼ同じ低電圧 で 2nd beam を変形させることができる. 以下同様にして, 全ての beam を変形させることができ，全体として大きな 変位量が得られる。

\section{3. 力測定の原理}

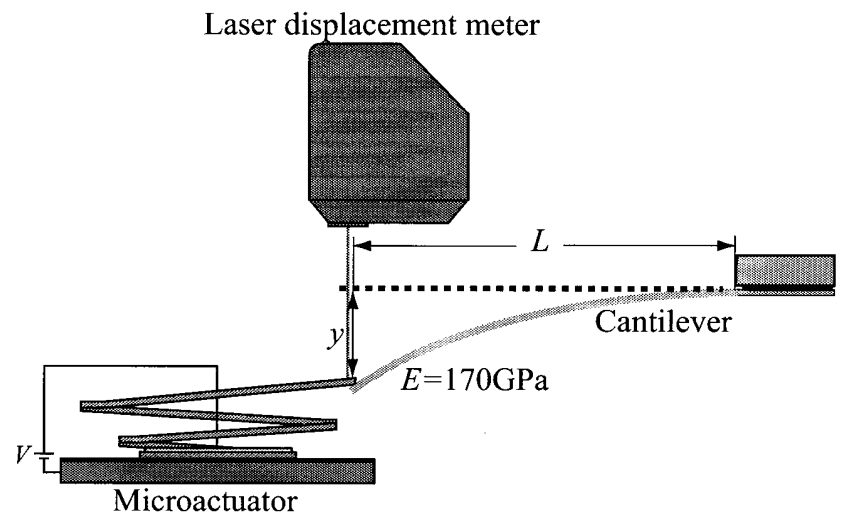

Fig. 2 Experimental setup for force measurement.

力測定の模式図を Fig.2 に示す.アクチュエータの出力 部分の下に, Si で製作した片持ち梁を挿入する.アクチュ エータに電圧を印加すると, 静電力によって片持ち梁が歪 み, その歪み量をレーザ変位計で計測する。その歪み量か ら以下の式を使って力 $F$ を算出する.

[No. 06-4] Proceedings of the 2006 JSME Conference on Robotics and Mechatronics, Waseda, Japan, May 26-28, 2006 


$$
F=\frac{6 E \cdot I_{z}}{2 L^{3}} y
$$

ただし， $E$ は $\mathrm{Si}$ のヤング率， $I_{Z}$ は断面二次モーメント， $L$ は片持ち梁の長さ, $y$ は片持ち梁の先端の歪み量である.

\section{4. 力特性の計測実験}

Type 1 と Type 2 のそれぞれについて寸法が異なる 2 種類 のアクチュエータを製作し，合計 4 種類のアクチュエータ の発生力を測定した. Fig.3に，その結果を示す. 印加電圧 を上げていくと，7V程度までは全てのアクチュエータの 発生力は電圧に比例して上昇したが，7Vを超えると寸法 $1500 \mu \mathrm{m}$ の Type 2 の発生力のみが急激に増大し, $20 \mathrm{~V}$ 程度 以下の低電压に扔いてこのアクチュエータのみが他よりも 大きな力を発生した. 以降では, この原因を考察する.

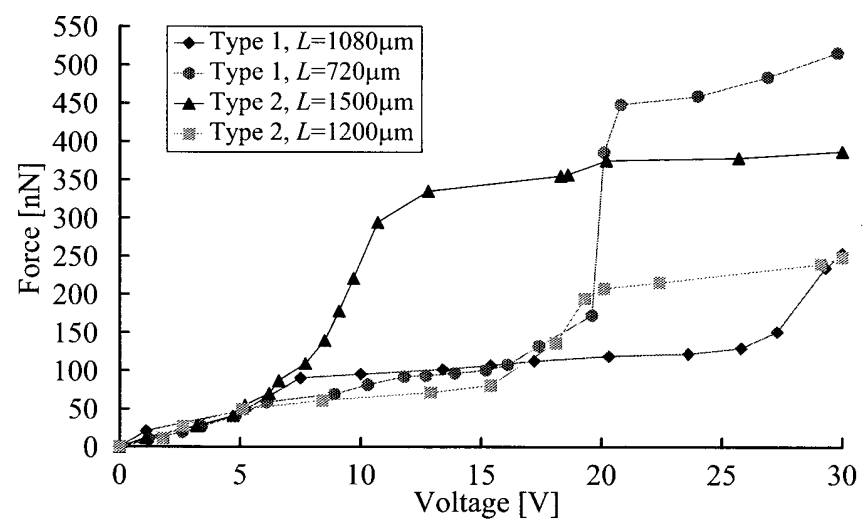

Fig. 3 Applied voltage vs. generated force.

無負荷状態において全ての beam が基板に接触するまで 変形寸るのに必要な電圧を調べると, Table 1 の結果となっ た. 寸法 $1500 \mu \mathrm{m}$ の Type 2 は最も低い電圧で変形できるた め, 力測定のための負荷を加えた場合でも低電圧で変形し やすく，その結果として大きな力を発生する。しかし，寸 法 $720 \mu \mathrm{m}$ の Type 1 と寸法 $1200 \mu \mathrm{m}$ の Type 2 も無負荷状態 では同程度の電圧で変形寸るため,これだけでは Fig. 3 の ような大きな違いが得られた理由を説明できない。

Table 1 Required voltage in case of no-load actuation.

\begin{tabular}{|c|c|c|}
\hline Actuator type & Actuator size, $L$ & Required voltage \\
\hline 1 & $1080 \mu \mathrm{m}$ & $26.0 \mathrm{~V}$ \\
\hline 1 & $720 \mu \mathrm{m}$ & $16.2 \mathrm{~V}$ \\
\hline 2 & $1500 \mu \mathrm{m}$ & $15.9 \mathrm{~V}$ \\
\hline 2 & $1200 \mu \mathrm{m}$ & $18.4 \mathrm{~V}$ \\
\hline
\end{tabular}

さらに詳細に原因を解明するために，電圧印加前におけ る各 beam 先端と基板との距離を計測した（Fig. 4). Type 2 では, 4th beam と 8th beam の先端は 1 st beam を除く他の全 ての beam 先端よりも基板に極めて近い位置にある。した がって, 電圧を印加すると, 1 st beam から先端に向かって beam が順番に変形するのではなく, 1st beam が基板に接触 した後は 4th beam と 8th beam が他の beamよりも先に基板 に接触するものと考えられる.したがって，寸法 $1500 \mu \mathrm{m}$ の Type 2 は比較的低い電圧でも 8 th beam を基板に接触させ ることが可能であり，これが低電圧における大きな発生力 につながる. 寸法 $1200 \mu \mathrm{m}$ の Type 2 の場合も 8th beam が 基板からほぼ同じ距離にあるが, beam の長さが短く変形し
難いために，低い電圧では 8th beam を基板に接触させられ なかったものと思われる. また, 寸法 $720 \mu \mathrm{m} の$ Type 1 の 場合は, 10th beam の先端が基板に近く配置されているが, Type 2 のつのアクチュエータよりもさらに beam が短い ために, 低い電圧では変形し難く大きな力を発生できなか ったものと思われる。

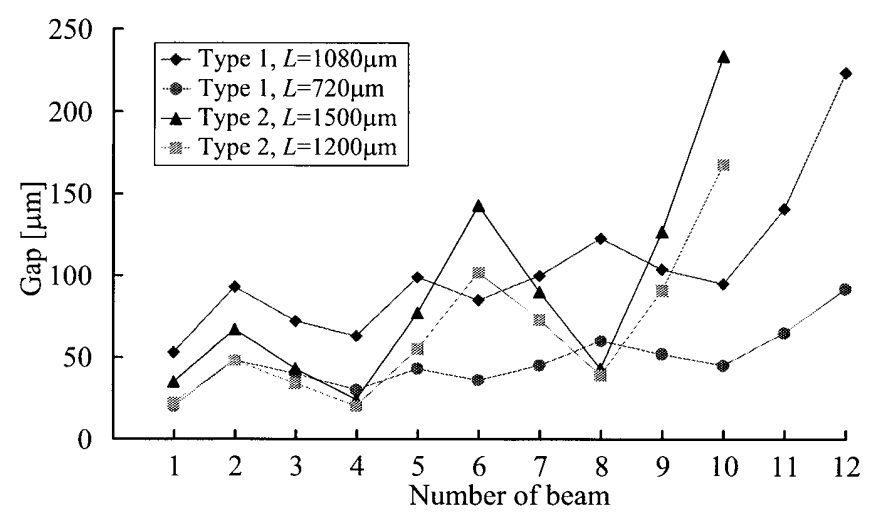

Fig. 4 Gap between tips of beams and a substrate.

なお， Type 2 の 4th beam が 2nd beam や 3rd beam より基 板に近い位置に配置されるのは，2nd beam が傾いているこ とに起因する。 Fig. 5 は, 1st beamから 4th beam までを, 1 st beam 側からと 4th beam 側から見た図である。2nd beam の傾きによって，3rd beam と 4th beam の先端が 2nd beam 先端より基板に近付くことが分かる. Type 1 でも同様のこ とが生じているが，その影響は Type 2 よりも小さい.

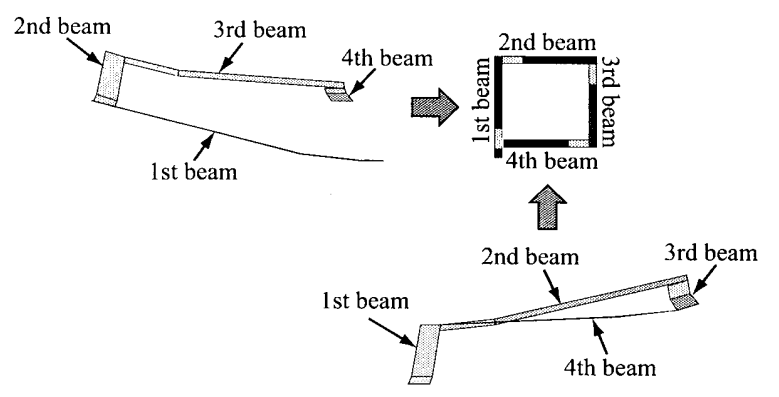

Fig. 5 Side views of an actuator composed of 4 beams.

\section{5. まとめ}

構造と寸法が異なる 4 種類の静電マイクロアクチュエー 夕について力計測を行い, 印加電圧と発生力の関係を調心 た。 その結果, 低電圧で大きな力を発生させるためには, 低電圧で大きな変形量が得られるような構造と寸法が必要 であることが分かった.すなわち, 基板からの距離が短く, なるべく長い beam を持つアクチュエータは, 駆動電圧が 低くなるため, 低電圧で大きな発生力を得ることが可能で ある.今後は，さらに駆動電圧を低くすることで，さらに 低電压で大きな発生力を得ることができるアクチュエータ を実現する。

\section{参考文献}

[1] Yuuki Kawamoto et al., "Electrostatic Microactuator with Au/poly-Si Bimorph Structure," Proceedings of the 21st Sensor Symposium, pp. 43-46, 2004.

[2] 樑町尚貴ら“"マイクロロボットのための静電マイクロアクチ ユエータの特性評価,”日本機械学会ロボティクス・メカトロ ニクス講演会, $2 \mathrm{~A} 1-\mathrm{N}-090,2005$. 